\title{
SURFACE CHARACTERIZATION AND FROTH FLOTATION OF FERGUSONITE FROM ABU DOB PEGMATITE USING A COMBINATION OF ANIONIC AND NONIONIC COLLECTORS.
}

\author{
Fawzy, M. M.* \\ *Nuclear Materials Authority, Cairo, Egypt.
}

\begin{abstract}
The performance of the mixed anionic (sodium oleate) / nonionic (sorbitan monooleate) collectors on fergusonite flotation and separation from silicate gangue minerals was investigated using the flotation tests. The surface characterization of fergusonite before and after the treatment with the mixed collectors was determined using the zetapotential measurements and FT-IR analyses. The results obtained from this study showed that the flotation recovery of fergusonite using sodium oleate enhanced in the presence of sorbitan monooleate and the optimum floatability was achieved at $\mathrm{pH} 5$ using $1 \mathrm{Kg} / \mathrm{Mg}$ blended collectors of sodium oleate and sorbitan monooleate as by a ratio 1:1 and methyl isobutyl carbinol (MIBC) as frother. It was also found that the addition of sodium metasilicate to citric acid as depressants showed a high affinity for silicate gangue minerals and weak affinity for fergusonite.
\end{abstract}

The zeta-potential and FT-IR measurements of fergusonite after the treatment with the mixed collectors indicated a strong adsorption of these molecules on the particle surface due to the chemisorptions.

Additionally, The SEM analysis of high-grade froth and its corresponding tailing product showed that the fergusonite mineral mostly concentrated in the froth, while the gangue silicate minerals relatively concentrated in the tailing.

Keywords: Fergusonite, sodium oleate, sorbitan monooleate, flotation, zeta-potential, FT-IR.

\section{INTRODUCTION}

There are about 250 minerals containing rare earth oxide elements (REOEs) which may be classified based on the composition of the REOEs into two main groups; the cerium group (light rare earth elements enriched) and the yttrium group (heavy rare earth elements enriched) (Bulatovic, 2010). The cerium group of rare earth minerals includes bastnasite... and monazite, and the yttrium group includes xenotime, fergusonite, and samarskite.

Fergusonite, a yttrium niobate $\left(\mathrm{YNbO}_{4}\right)$, is a complex oxide that contains various rare earth elements with yttrium and niobium as dominant components. The mineral has tetragonal crystal symmetry. In the structure, rare earth elements often substitute for the yttrium, making this an important mineral in rare earth deposits.

The beneficiation of the rare earth (RE) minerals from their ores depends on the physical and chemical properties of all the minerals in the ore and the liberation size of the RE minerals. Owing to their high densities, magnetic properties, and surface 
properties, RE minerals can be separated from their ores by applying gravity separation, magnetic separation, flotation, and electrostatic separation methods (Jordens et al., 2013; Satur et al., 2016). An example of the beneficiation of RE mineral as samarskiteY, Raslan, 2009 indicates that the heavy mineral occurrence with a significant (approximately $1.5 \mathrm{wt}$. \%) occurrence of samarskite (Y) was subjected to lab-scale separations. This work used sieving, desliming, gravity separation (using a shaking table), and magnetic separation to produce a samarskite (Y) concentrate.

Flotation is a useful approach for fine-grained RE occurrences where other physical separation methods prove to be impractical. The most common collectors used for flotation of rare earth oxide minerals include variations of hydroxamates, fatty acids, dicarboxylic acids, and organic phosphoric acids (Zhang and Edward, 2012; Jordens et al., 2014). Fatty acids have traditionally been the collectors of choice in RE mineral flotation due to their low cost and widespread availability in mineral flotation. Another reason for their frequent use in flotation is that sodium oleate is one of the most extensively researched flotation collectors (Bulatovic, 2010). A most common depressant group used in RE mineral flotation includes sodium silicate, sodium hexafluorosilicate, lignin sulfonate, and sodium carbonate (Houot et al., 1991). Sodium silicate has been reported as having a week affinity for RE minerals at low dosage but a much higher affinity for silicate gangue minerals (Houot et al., 1991).

Additionally, the researchers found that the recovery of RE mineral is strongly dependent on the type of frother used (Anderson, 2016).

There is little information currently in the literature about flotation or surface characterization of fergusonite. The recent paper have been published for studying some surface chemistry analysis of fergusonite, and the bubble-particle attachment, as well as adsorption of sodium oleate on fergusonite, to lesser degree, potassium amyl xanthate onto the surface (Malas et al., 2013).

There are comprehensive studies on the interaction between ionic-nonionic surfactants in aqueous systems, but there are limited studies concerning the adsorption of mixed surfactants at the mineral surfaces, which should be contributed because the underlying mechanisms of the synergistic behavior remain not well-understood (Wang et al., 2015).

Qun et al., 1991 and Wang et al., 2015 manifested that the adsorption of the ionic surfactant (anionic and cationic) was enhanced by the presence of the nonionic surfactant. They also proved that chain-chain interaction between the adjacent ionic and nonionic surfactants on the particles has been proposed to be responsible for the enhanced adsorption.

In this study, the surface characterization of fergusonite from Abu Dob pegmatite using zeta-potential and FT-IR measurements as well as its flotation separation from the associated minerals which consisting mainly of silicate minerals (quartz, feldspar, and zircon) was investigated using combination of anionic (sodium oleate) and nonionic (sorbitan monooleate) surfactants. 


\section{MATERIALS AND MethodS}

\subsection{Materials}

\subsubsection{Ore sample}

Fergusonite ore sample was obtained from Abu Dob pegmatite bodies in South Eastern Desert of Egypt. This ore contained about 28 wt. \% of both valuable zircon and fergusonite minerals related to the original bulk sample. Quartz and feldspar were the main components gangue minerals that represented about 72 wt. \%. Abu Dob pegmatite ore was subjected to lab-scale physical separation to produce fergusonite concentrate in the size range $0.063-1 \mathrm{~mm}$. This work was done according to the following procedure:

- A feed of Abu Dob pegmatite consisting of fergusonite, zircon, quartz, and feldspar was deslimed and then sieved to $100 \%$ passing $1 \mathrm{~mm}$.

- The sieved material was sized to different size fractions, and individually fed to a gravity-shaking table to produce a concentrate of zircon and fergusonite as heavy fractions.

- The heavy fractions were then subjected to magnetic separation using high intensity left-type magnetic separator, (Carpco), Model [MLH (13) 111-5] to obtained fergusonite concentrate as magnetic fraction and zircon concentrate as non-magnetic fraction (Raslan \& Mona, 2017 in preparation).

\subsubsection{Pure minerals}

Four pure mineral samples of fergusonite, zircon, quartz and feldspar were obtained from the concentrated product of Abu Dob pegmatite physically separated sample. These pure minerals samples were crushed then ground using a mortar to passing $100 \%$ from $63 \mu \mathrm{m}$ sieve to be ready for the flotation experiments.

\subsubsection{Reagents}

In the flotation experiments, anionic collector sodium oleate, and nonionic surfactant sorbitan monooleate (span 80) were applied as mixed collectors for fergusonite mineral. Sodium metasilicate, oxalic acid, and citric acid were investigated as depressants for the gangue minerals. Analytical grade of sodium hydroxide and hydrochloric acid were used as pH adjusters. The frother used was methyl isobutyl carbinol (MIBC).

\subsection{Methods}

\subsubsection{Sample characterization}

Individual samples of purified fergusonite, zircon, quartz, and feldspar were analyzed chemically by scanning electron microscope (SEM). This instrument includes a Philips XL 30 energy-dispersive spectrometer (EDX) unit.

Some of the selective picked grains of fergusonite and zircon were confirmed by X-ray diffraction technique (XRD) using Philips X-ray generator model PW 3710/31 a diffractometer with automatic sample changer model PW1775 (21 position). The X-ray radiation used is $\mathrm{Cu}$-target tube and $\mathrm{Ni}$ filter at $40 \mathrm{kV}$ and $30 \mathrm{~mA}$. 


\subsubsection{Zeta-potential measurements}

The zeta-potential measurements were carried out using a Malvern zetasizer nano series- zs instrument. Prior to the measurements, all samples were hand ground in a mortar and pestle and $100 \%$ passing $63 \mu \mathrm{m}$. For all testes, $0.1 \mathrm{~g}$ of material was agitated in $50 \mathrm{ml}$ of $0.01 \mathrm{M} \mathrm{NaNO}_{3}$ solution as the supporting electrolyte. Sodium hydroxide and hydrochloric acid were used as $\mathrm{pH}$ modifiers. All testes were carried out at $\mathrm{pH}$ range 2-11, and each experiment was repeated three times to ensure repeatability and provide a standard deviation of the isoelectric point $\mathrm{pH}$ value $( \pm 0.1 \mathrm{mV})$.

\subsubsection{FT-IR measurements}

The Fourier Transform Infrared (FT-IR) analysis was performed for the collector and dried pure fergusonite sample before and after the flotation experiments to determine the availability of collector adsorption on the mineral surface. Using FT-IR Model Cary 630 FT-IR spectrometer for both Qualitative and Quantitative (for liquid samples) analysis produced by Agilent technologies Company, samples were investigated in spectral range (wave numbers $\mathrm{cm}^{-1}$ ) from $4000 \mathrm{~cm}^{-1}$ to $400 \mathrm{~cm}^{-1}$ without any treatment.

\subsubsection{Flotation measurements}

Micro-flotation cell was used for small-scale flotation experiments. In each test, $3 \mathrm{~g}$ of pure mineral was conditioned in $40 \mathrm{~cm}^{3}$ of collector solution of predefined concentration for $5 \mathrm{~min}$ and the suspension was then transferred to a $50 \mathrm{~cm}^{3}$ flotation column $\left(10 \mathrm{~cm}\right.$ high $\times 5 \mathrm{~cm}^{3}$ cross-section) with its stopper closed to prevent solution filtration. Air was introduced at a flow rate of $50 \mathrm{~cm}^{3} / \mathrm{min}$, and flotation was performed for $2 \mathrm{~min}$. The froth was skimmed from the top of the column into a beaker with the aid of a clean glass plate. At the end of the test, both the froth and sink products were filtered, dried, and weighed. The flotation recovery was calculated as the weight ratio of the floated pure mineral to the total mineral expressed as a percentage. The froth and sink products were analyzed chemically by SEM analysis.

\section{RESULTS AND DISCUSSION}

\subsection{Characterization of the Samples}

The characterization of pure minerals was achieved by EDX and XRD analysis. A pure sample of fergusonite was ground, sieved to $<63 \mu \mathrm{m}$, and analyzed using scanning electron microscope. The EDX chemical analysis data of fergusonite (Fig.1A) showed that it contained about $40 \%$ niobium, 5\% tantalum, 15\% yttrium, and $26 \%$ rare earth elements as well as $2.7 \%$ uranium and $3.5 \%$ thorium. Figure $2 \mathrm{~A}$ shows the XRD confirmation data of fergusonite, as well as binocular microscope picture.

Zircon, quartz, and feldspar are the most common associated minerals for fergusonite. Therefore, the purified individual samples of these minerals were used for the flotation experiments. Figure $1 \mathrm{~B}$ shows the results of EDX analysis data of zircon, which contained about 50\% zirconium, $19 \%$ silicon, $11 \%$ thorium, $6 \%$ uranium, $4 \%$ hafnium, and $3 \%$ ytterbium as well as $\mathrm{Al}, \mathrm{Fe}$, and $\mathrm{Ca}$. Zircon was confirmed by using the XRD analysis (Fig. 2B). Additionally, Figure 1C\&D shows the EDX result of quartz and feldspar samples. 


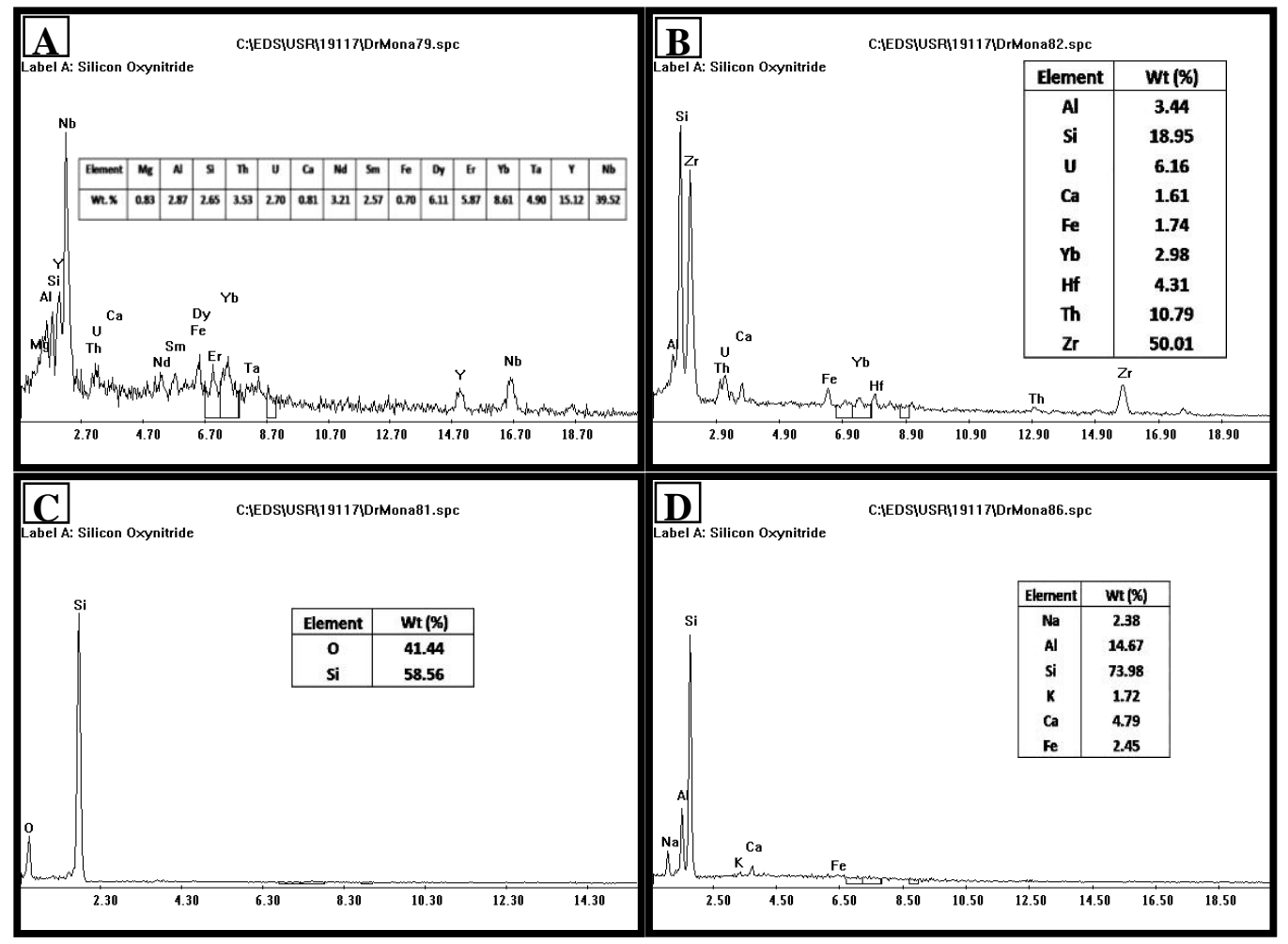

Fig. 1: EDX analysis data of fergusonite A, zircon B, quartz C, and feldspar D.

\subsection{Zeta-potential Measurements}

The isoelectric point (IEP) is a very important property that can be used to characterize the electrical double layer of the mineral surface in flotation, which is the $\mathrm{pH}$ value at which the zeta-potential is zero (Pope and Sutton, 1973). Understanding the zetapotential of a mineral, and the IEP, combined with knowledge of a collector's ionization behavior at various $\mathrm{pH}$ levels in aqueous conditions, allows one to predict the mechanism of collector adsorption on the mineral surface (Pope and Sutton, 1973; Cheng et al., 1993; Kosmulski, 2009).

The zeta-potential results of all minerals in the absence of the collectors are shown in Fig. 3. It can be seen from Fig. 3 that the zeta-potential of all minerals showed negative values with the increasing $\mathrm{pH}$. The isoelectric points (IEP) of fergusonite and zircon were determined as 2.7 and 2.3 , respectively. The surface potential of quartz and feldspar remained negative at all tested $\mathrm{pH}$ values. The data for quartz and feldspar match well with the expected trend, having a zeta-potential that is negative across the $\mathrm{pH}$ range investigated, which corresponds to previous work (Kosmulski, 2009). The data for IEP of fergusonite was obtained different from the literature (Malas et al., 2013) that the isoelectric point of fergusonite was between 6 and 6.5. A range of IEP (49) of zircon was reported in literature, which also shows discrepancies with the data of this work (Kosmulski, 2009).

These discrepancies for the variability in IEP values observed for minerals may be due impurities, differences in the mineral composition or to lattice damage caused by radiation due to the presence of uranium and thorium (Jordens et al., 2013). 

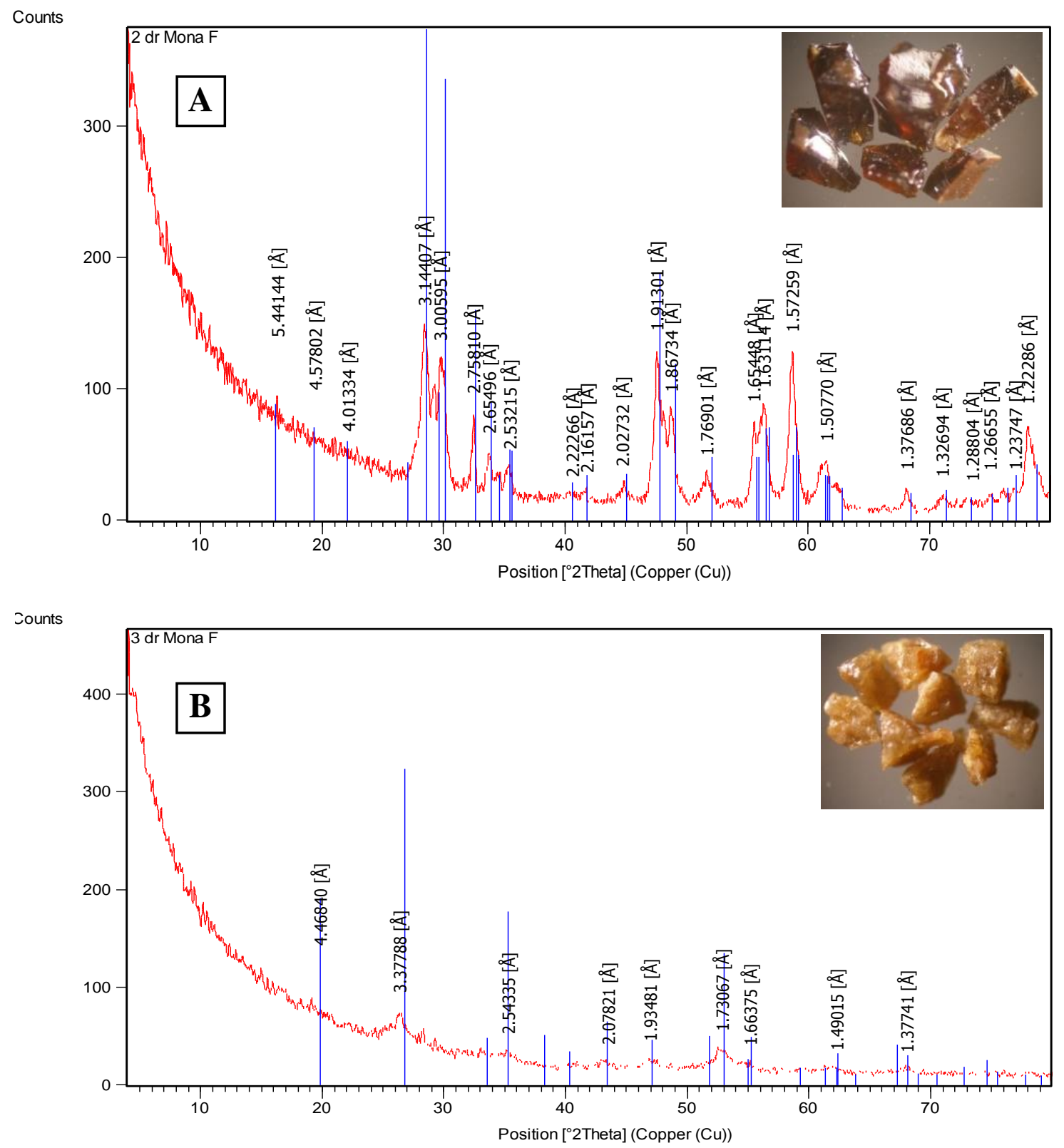

Fig. 2: X-ray diffraction patterns; (A) fergusonite (ASTM card no. 9-0443), (B) zircon (ASTM card no.01-081-0591).

\subsection{Micro-flotation Experiments}

The micro-experiments were carried out using purified individual minerals to investigate their flotation behavior in different conditions. The effects of collector concentration and $\mathrm{pH}$ were evaluated initially on the fergusonite flotation alone, and then the optimum conditions obtained were tested on the flotation of zircon, quartz, and feldspar minerals. The various depressants were used to modify the flotation response of selected minerals. Since the flotation experiments were conducted using pure minerals, the floatability results were expressed on a weight basis, meaning that they were stated as mass of mineral floated as opposed to conventional concentration recoveries. 


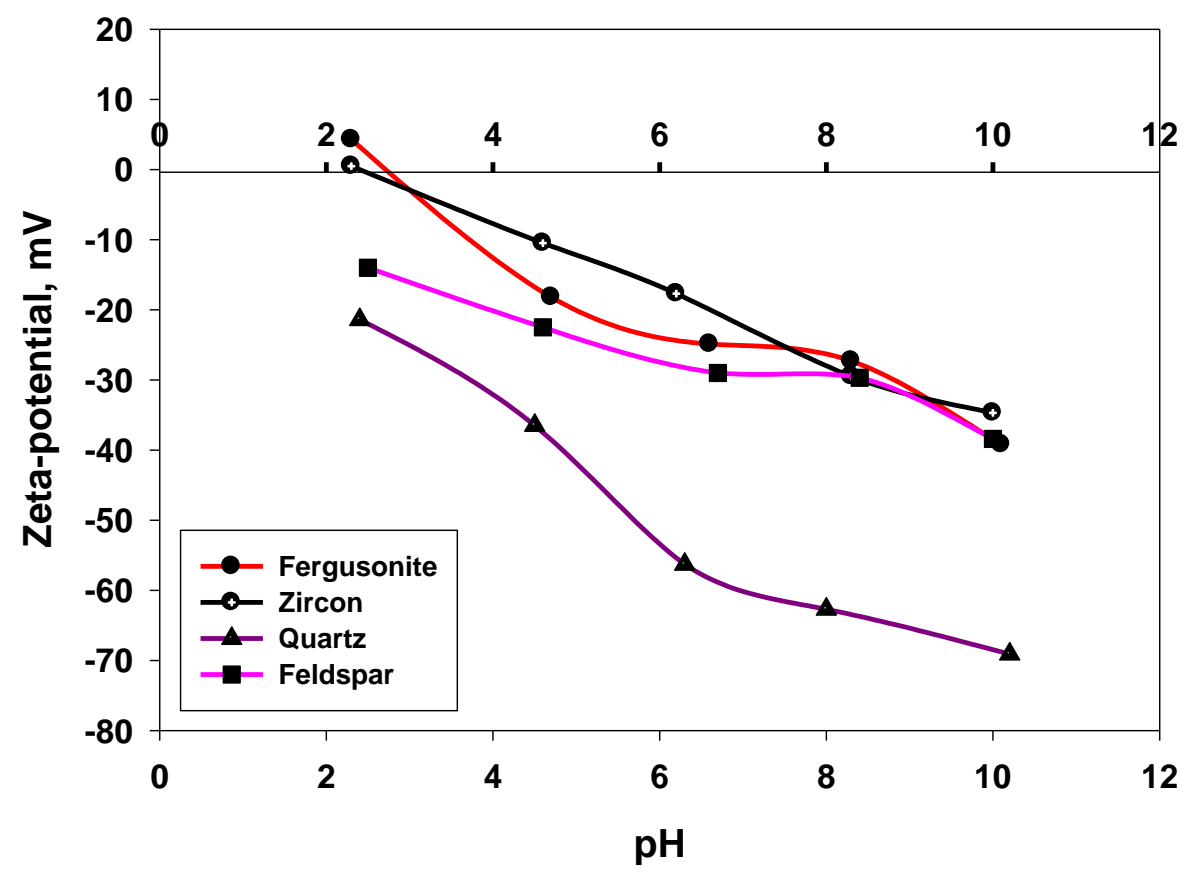

Fig. 3: Effect of pH on zeta-potential of pure fergusonite, zircon, quartz, and feldspar minerals.

\subsection{Effect of Collector and Concentration}

The micro-flotation experiments were carried out firstly using sodium oleate alone, and then with the mixture of sodium oleate and sorbitan monooleate ( $\operatorname{span} 80$ ) to decide finding the most suitable alternative. Initially a dosage of $1 \mathrm{Kg} / \mathrm{Mg}$ was chosen for each collector under the fixed conditions $<63 \mu \mathrm{m}$ grain size and MIBC as frother at $\mathrm{pH} 5$. As can be seen from Fig. 4, when sodium oleate alone was used for the flotation experiments, the flotation recovery of fergusonite was obtained as $44 \%$, while the fergusonite recovery reached $96 \%$ at the same concentration of sodium oleate mixed with span 80 by a ratio of $1: 1$. The ultimate recovery of fergusonite was $64 \%$ at 2 $\mathrm{Kg} / \mathrm{Mg}$ of collector dosage whereas the ultimate recovery was found to be $98.8 \%$ using the blend of sodium oleate and span 80. It was concluded that the poor results were achieved using sodium oleate alone. However, by addition of nonionic surfactant (span 80) with a ratio $1: 1$, the floatability was enhanced. The fergusonite floatability showed no significant improvement by using the collector dosage from 1 to $2 \mathrm{Kg} / \mathrm{Mg}$ (96 to $98.8 \%$ respectively) therefore using $1 \mathrm{Kg} / \mathrm{Mg}$ of mixed collector was enough to float fergusonite efficiently.

\subsection{Effect of pH}

The $\mathrm{pH}$ of the slurry is perhaps the most important parameter in separating minerals by flotation. Figure 5 illustrates the flotation response of fergusonite as a function of $\mathrm{pH}$ at $1 \mathrm{Kg} / \mathrm{Mg}$ dosage of sodium oleate and $1 \mathrm{Kg} / \mathrm{Mg}$ mixture of sodium oleate and span 80 using MIBC. The maximum floatability of fergusonite using sodium oleate alone reached to $44 \%$ at $\mathrm{pH} 5$ then the recovery decreased sharply at higher $\mathrm{pH}$ values. The flotation of fergusonite showed a maximum floatability (96\%) also at $\mathrm{pH} 5$ using a blend of sodium oleate with span 80 then the floatability decreased. Figure 3 showed that the fergusonite had a positive surface charge at $\mathrm{pH}<2.7$ and become negative at 
higher $\mathrm{pH}$ values. Thus, the high floatability of fergusonite at $\mathrm{pH} 5$ may be due to chemisorption of the collector (both mineral and collector have negative charges) (Somasundaran and Ananthapadmananthan, 1986). The decrease in the floatability at $\mathrm{pH}>5$ may be due to high repulsion with a negative collector caused by increase in the negativity of the mineral surface.

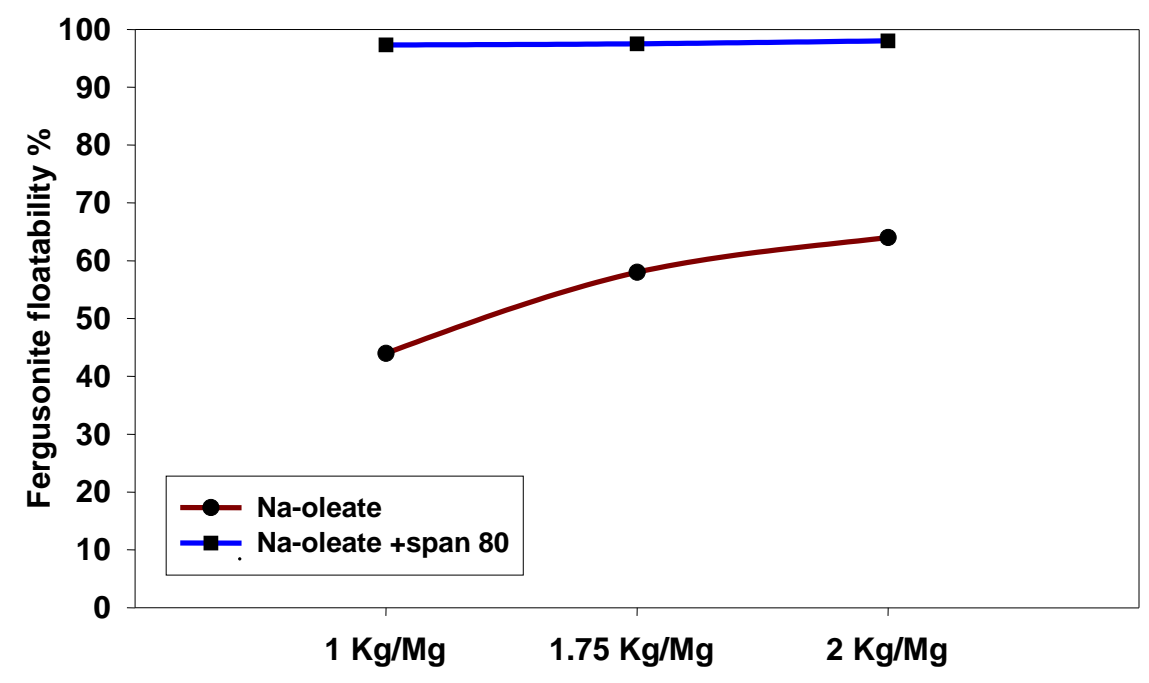

Fig. 4: Effect of collector dosage on floatability of fergusonite using sodium oleate and mixture of sodium oleate and span 80.

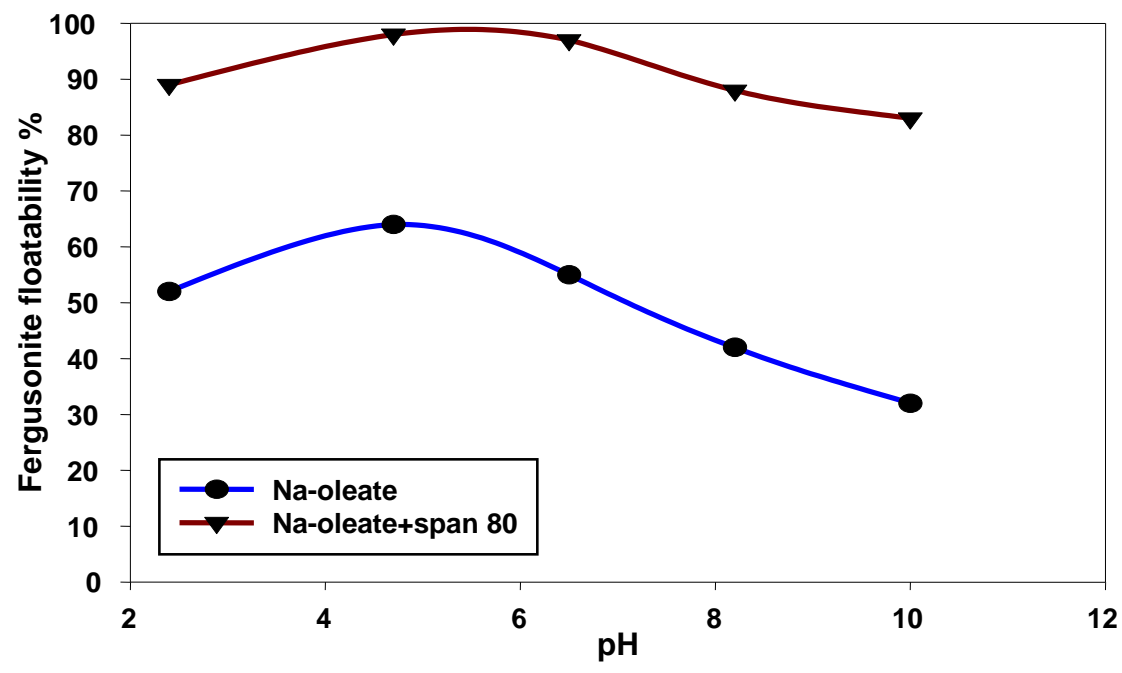

Fig. 5: Effect of pH on floatability of fergusonite surface using Na-oleate and the mixture collectors.

\subsection{Effect of Depressant Addition}

Depressants are reagents added to flotation in order to selectively retard or stop the flotation of a specific mineral or group of minerals. The various depressants were selected as sodium metasilicate, oxalic, and citric acid to evaluate the effect of them on the floatability of the most common gangue minerals. Sodium metasilicate is commonly used for depressing silicate minerals as well as iron oxide (Nascimento et al., 2013). 
Organic acids have been used as gangue depressants during flotation of ores containing oxide minerals. The most widely used organic acids are citric, oxalic, and tartaric acid. Both oxalic and citric acids are widely used during niobium/zirconium separation as zirconium depressant and also during flotation of RE oxides as gangue depressant (Bulatovic, 2010).

The floatability of quartz, feldspar, and zircon was evaluated firstly using the optimum conditions obtained for the flotation of fergusonite $(1 \mathrm{Kg} / \mathrm{Mg}$ mixture of sodium oleate and span 80 as collector by ratio 1:1 and MIBC at pH 5). (Fig. 6)The results indicated that the floatability of fergusonite, zircon, quartz, and feldspar as a separate mineral without any depressants addition were $97.3,39.7,23.3$, and $25 \%$ respectively. Then, the floatability of the gangue minerals evaluated as function of $400 \mathrm{~g} / \mathrm{Mg}$ sodium metasilicate addition. The floatability of zircon, quartz, and feldspar were seen to be as low as at 21, 12 and $10 \%$, respectively, while fergusonite floatability was $95.7 \%$.

The flotation response of fergusonite, zircon, quartz, and feldspar in the presence of 400 $\mathrm{g} / \mathrm{Mg}$ sodium metasilicate and $500 \mathrm{~g} / \mathrm{Mg}$ oxalic acid mixture were seen to be as 95.3 , $12.5,5.4$, and $4.2 \%$, respectively. Finally, the mixture of $400 \mathrm{~g} / \mathrm{Mg}$ sodium metasilicate with $500 \mathrm{~g} / \mathrm{Mg}$ citric acid was tested. The results showed that the floatability of fergusonite, zircon, quartz, and feldspar reached to the lowest as seen in Fig. 6. It is concluded from these results that mixture sodium metasilicate with citric acid were the potential depressants for the ore sample and these mixture of depressants had very low affinity for the floatability of fergusonite.

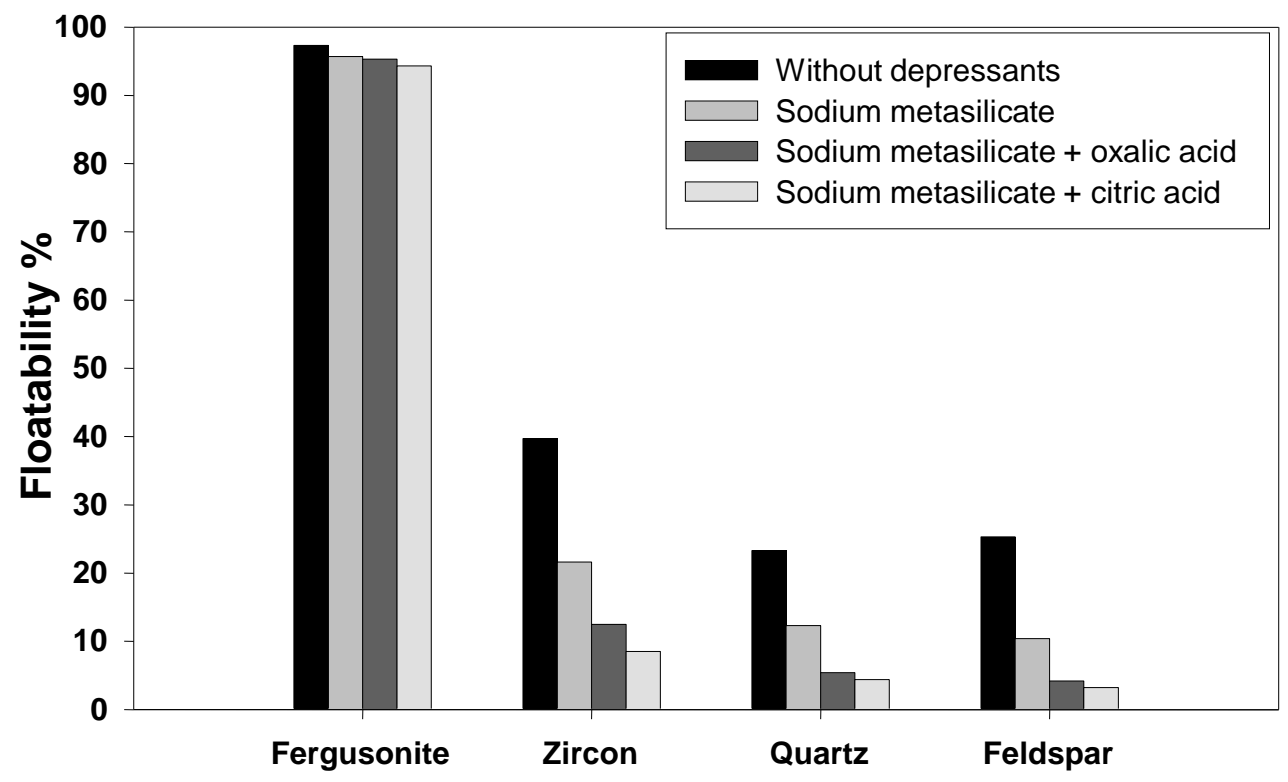

Fig. 6: Effect of addition of depressants on floatability of fergusonite and associated gangue minerals (zircon, quartz, and feldspar).

\subsection{Effect of Mixture Collectors on Zeta-potential of Fergusonite}

The addition of mixture of sodium oleate to sorbitan monooleate collectors changed the zeta-potential of fergusonite more negative, and the IEP was shifted towards to lower $\mathrm{pH}$ values. The change in the zeta-potential of the fergusonite mineral indicated that the 
mixture of collectors adsorbed on the surface of the fergusonite. Figure 7 shows the change in the potential of the fergusonite surface before and after the treatment with mixed collector.

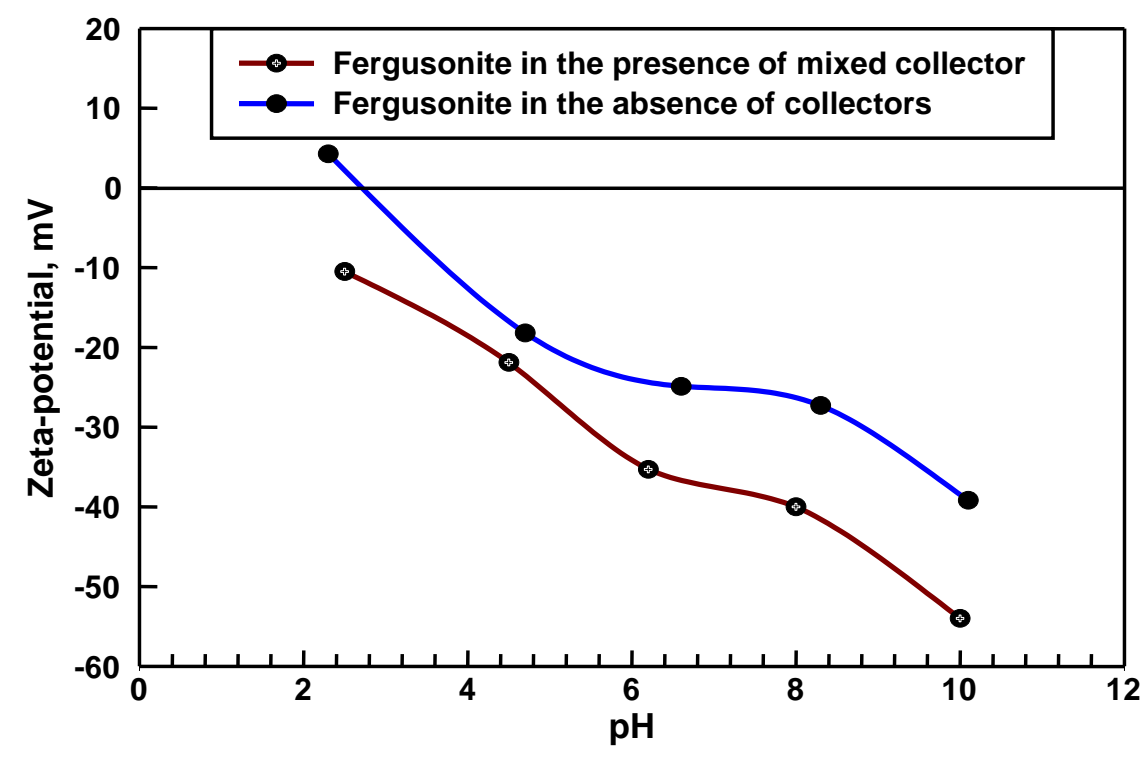

Fig. 7: Effect of mixture of sodium oleate and span 80 on zeta-potential of fergusonite.

\subsection{FT-IR Results}

To understand the interaction of collector mixture (sodium oleate and sorbitan monooleate) on fergusonite mineral, the FT-IR analysis was performed. Figure 8 shows the infrared spectra of collector mixture. The spectra of the collector mixture at 3258 $\mathrm{cm}^{-1}$ is the characteristic of the $\mathrm{O}-\mathrm{H}$ stretching vibration of the acid. Bands between $2300-2000 \mathrm{~cm}^{-1}$ are the characteristics for C-C triple bond of alkynes. The strong band at $1633 \mathrm{~cm}^{-1}$ is the characteristic of $\mathrm{C}-\mathrm{C}$ double bond. If there is a coupling between $\mathrm{C}=$ $\mathrm{C}$ group and $\mathrm{C}=\mathrm{O}$ of ester, the intensity will increase due to the increase in dipole momentum in double bond (Coates, 2000). The FT-IR spectra of fergusonite in the absence and presence of collector mixture is shown in Fig. 9. The FT-IR spectra of fergusonite showing bands between 3500 and $3750 \mathrm{~cm}^{-1}$ are due to the stretching vibrations of the $\mathrm{O}-\mathrm{H}$ groups. The bands between 900 and $1150 \mathrm{~cm}^{-1}$ are attributed to the $\mathrm{Si}-\mathrm{O}$ stretches and $\mathrm{Si}-\mathrm{O}-\mathrm{Si}$ stretching vibration modes (Coates, 2000). The bands between $500-1000 \mathrm{~cm}^{-1}$ are assigned to bond between groups II-III transition metal cations in spinel oxides and oxygen anion (Povnnennykh, 1978). The band observed at $581 \mathrm{~cm}^{-1}$ is assigned to Fe-O bending vibration (Liese, 1967; Kim et al., 2007). The FTIR spectra of fergusonite after being treated with collector mixture shows new adsorption bands. The characteristic alkyl chain bands at 2920 and $2850 \mathrm{~cm}^{-1}$ are due to asymmetric and symmetric $\mathrm{C}-\mathrm{H}$ stretching vibrations of $\mathrm{CH}_{2}$ group. The bands between $2300-2000 \mathrm{~cm}^{-1}$ are the characteristic peaks of C-C triple bond of collector mixture. However, the frequency of bands hardly changed compared with Fig. 8. The band at $1736 \mathrm{~cm}^{-1}$ is the characteristic of $\mathrm{C}=\mathrm{O}$ of ester from sorbitan monooleate. The IR spectrum alteration of the fergusonite before and after treatment with the mixed collectors (Fig.9) indicates complete adsorption of collector on the fergusonite surface. 


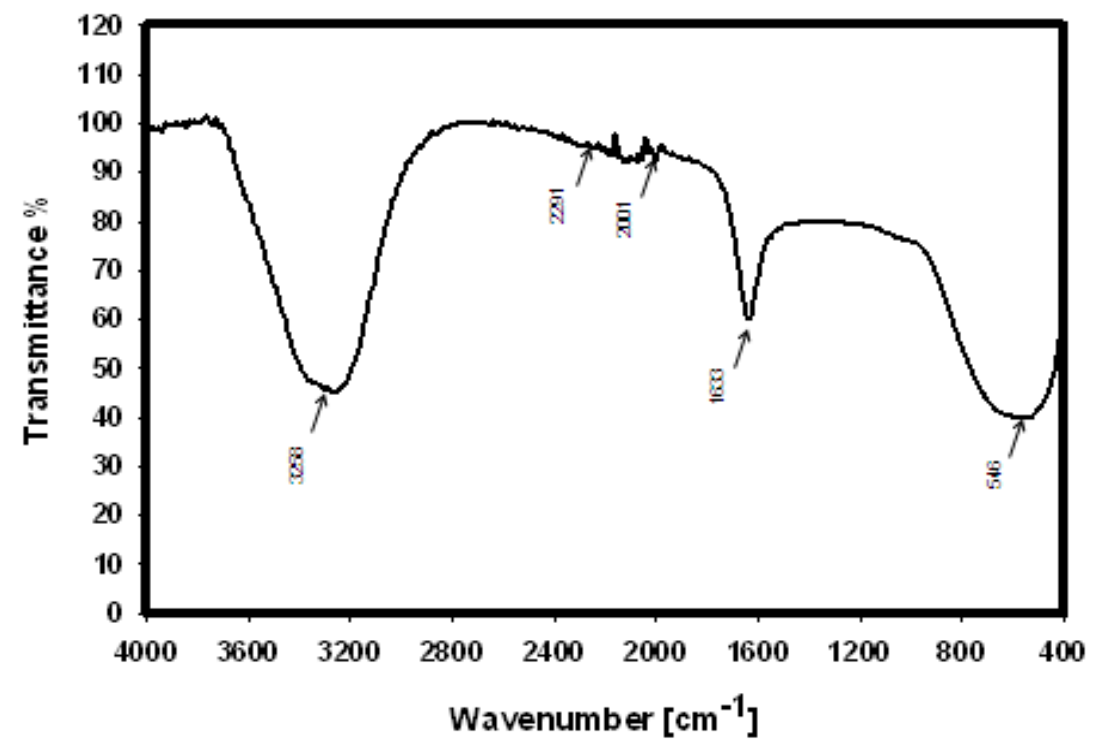

Fig. 8: FT-IR spectra of collector mixture.

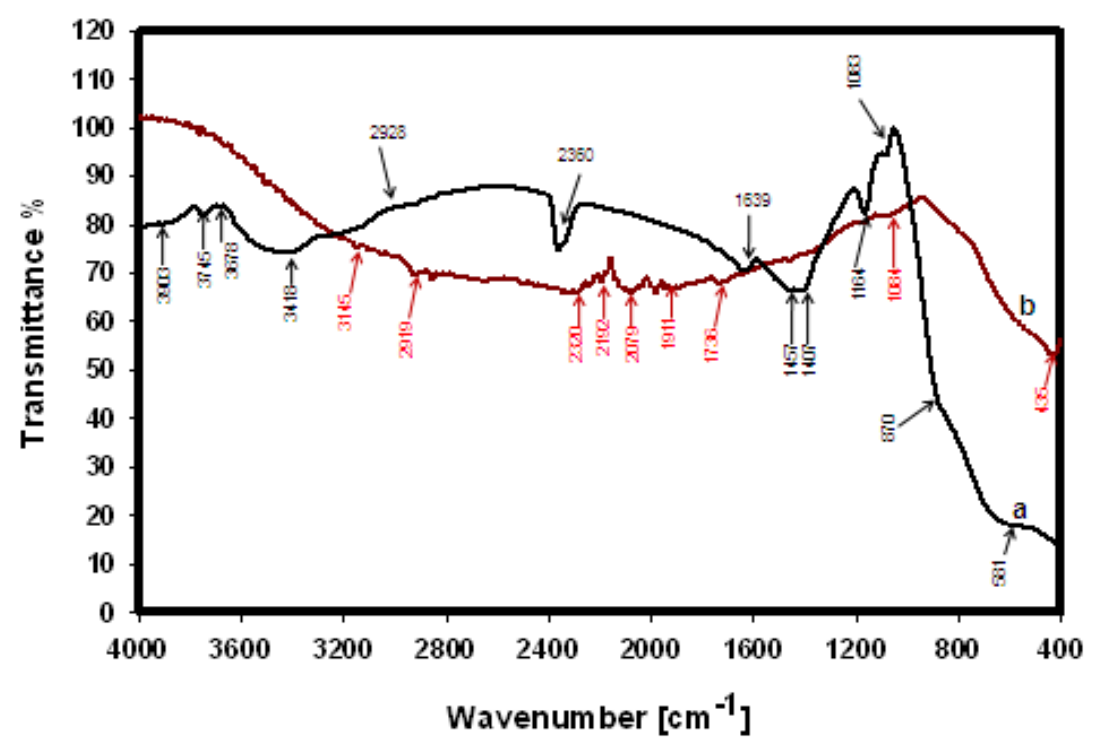

Fig. 9: FT-IR spectra of fergusonite (a), fergusonite treated with mixed collector (b).

\subsection{Flotation of Abu Dob Fergusonite Sample}

The micro-flotation experiments were conducted with the fergusonite ore from Abu Dob pegmatite sample to increase the rare earth content of the sample.

The micro-flotation experiments were carried out as $1 \mathrm{Kg} / \mathrm{Mg}$ combination of sodium oleate and sorbitan monooleate as the collectors by a ratio $1: 1$ and $400 \mathrm{~g} / \mathrm{Mg}$ sodium metasilicate with $500 \mathrm{~g} / \mathrm{Mg}$ citric acid as well as MIBC at $\mathrm{pH} 5$ and $<63 \mu \mathrm{m}$ grain size. The EDX evaluation indicated that the micro-flotation separation was very successful, as $37 \% \mathrm{Nb}, 14 \% \mathrm{Y}, 20 \% \mathrm{REE}, 8 \% \mathrm{Th}$, and $3 \% \mathrm{U}$ were determined in the froth fraction. While the sink fraction contained $33 \% \mathrm{Si}, 25 \% \mathrm{Zr}, 6 \% \mathrm{Al}, 12 \% \mathrm{Nb}$, and $7 \% \mathrm{Y}$. (Fig.10). 


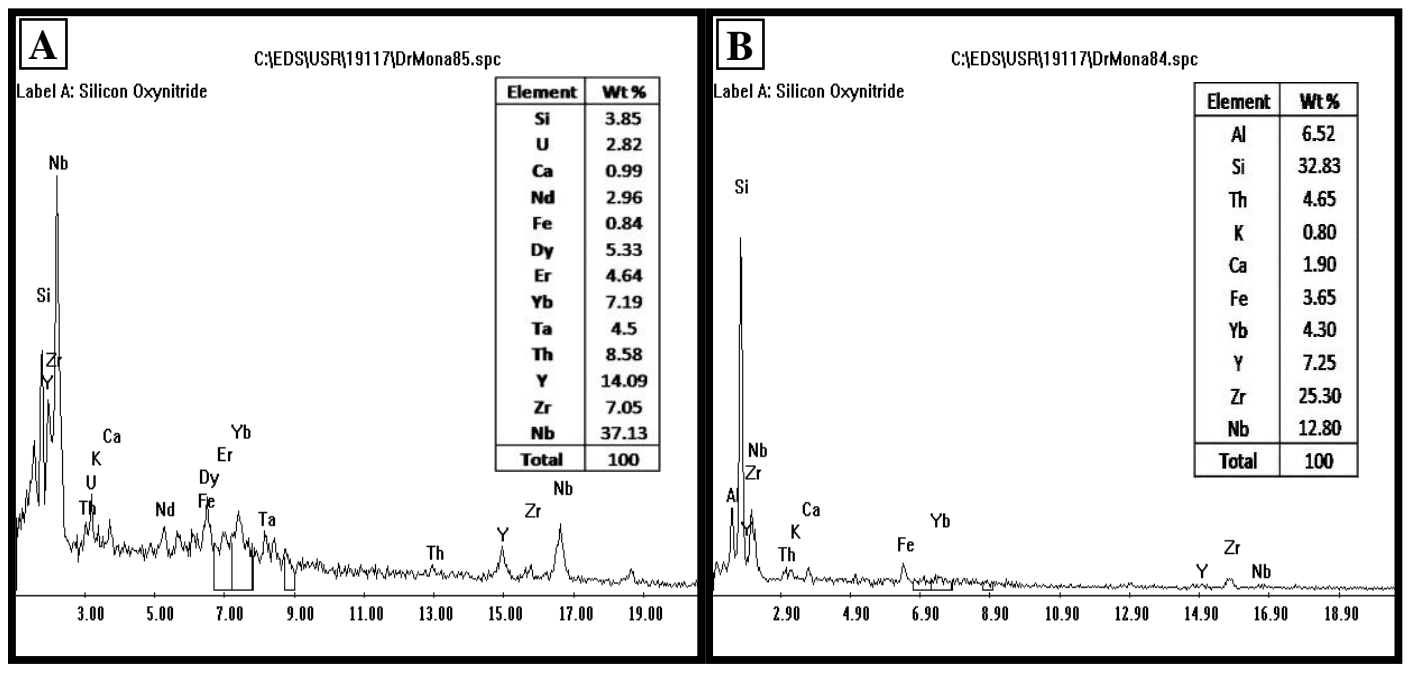

Fig. 10: EDX analysis data of froth (A), sink (B) products.

\section{Conclusions}

- The results of the micro-flotation experiments confirmed that the flotation response of fergusonite is not similar to that of its gangue minerals. The optimum floatability of fergusonite is achieved at $\mathrm{pH} 5$ using $1 \mathrm{Kg} / \mathrm{Mg}$ blended collectors of sodium oleate and sorbitan monooleate as by a ratio 1:1 and MIBC. The use of combining different depressants on the surface properties and flotation behavior of these minerals enhance the separation of fergusonite from its associated minerals where sodium metasilicate appears to be the most effective depressant for silicate minerals as quartz and feldspar while citric acid used as a depressant for zircon.

- The isoelectric point (IEP) of fergusonite and zircon are at pH 2.7 and 2.3, respectively but the surface potential of quartz and feldspar remained negative at all $\mathrm{pH}$ values. The addition of sodium oleate as well as span 80 as collectors shifted the surface potential of fergusonite towards negative values due to interaction of collectors' molecules with lattice atoms. Sodium oleate with sorbitan monooleate adsorbed on the negatively charged mineral surfaces, which may verify that chemisorption took place. The results of the zeta-potential and the alteration of IR spectra of fergusonite sample after the conditioning with the mixed collectors confirmed that the chemical nature of mixed collector adsorption on fergusonite surface.

\section{REFERENCES}

[1] Anderson, D.; Taylor, R. and Erson, G.: "Rare earth flotation fundamentals: A review". Inter. Miner. Processing Congress Proceedings, ISBN: 978-1-926872-29-2, pp. 1-15, (2016).

[2] Bulatovic, M.: "Flotation of REO minerals, In: Handbook of flotation reagents: Chemistry, theory and practice". $1^{\text {st }}$ ed. Elsevier Science, Amsterdam, NL, pp. 151173, (2010).

[3] Cheng, W.; Holtham, N. and Tam, T.: "Froth flotation of monazite and xenotime". Miner. Eng. 6, pp. 341-351, (1993).

[4] Coates, J.: "Interpretation of infrared spectra, a practical approach". Encyclopedia of Analytical Chemistry, John Wiley \& sons Ltd, Chichester, pp. 10815-10837, (2000). 
[5] Houot, R.; Cuif, P.; Mottot, Y. and Samama, C.: "Recovery of rare earth minerals with emphasis on flotation process, In: Inter. Conf. on Rare earth minerals and minerals for electronic uses". Prince Songkla University, Hat Yai, TH, pp. 301-324, (1991).

[6] Jordens, A.; Cheng, P. and Waters, E.: "A Review of the beneficiation of rare earth element bearing minerals". Min. Eng., 41, pp. 97-114, (2013).

[7] Jordens, A.; Marion, C.; Kuzmina, O. and Waters, E.: "Surface chemistry consideration in the flotation of bastnasite". Min. Eng. 66-68, pp. 119-129, (2014).

[8] Kim, J.; Lim, B.; Jeong, K.; Cho, W. and Choa, B.: "Surface modification of magnetite nanoparticles for immobilization with iysozyme". Jou. of ceramic processing research, 8, 4, pp. 293-295, (2007).

[9] Kosmulsky, M.: "Surface charging and points of zero charge". Vol. 145, p. 1092, (2009).

[10] Liese, H. C.: "Mineralogical notes an infrared absorption analysis of magnetite". American mineralogist, 52, pp. 198-205, (1967).

[11] Malas, K. W.; Jordens, A.; Mirnezami, M.; Chu, P.; Gauvin, R. and Waters, K. E.: "Surface characterization of fergusonite". Canadian metallurgical quarterly, Vol. 52, No. 3, pp. 278-284, (2013).

[12] Nascimento, R.; Pereira, D. and Lima, R. M. F.: "Influence of sodium silicate on floatability and charge of hematite and quartz with sodium oleate". Latin American applied research. 43, pp. 189-191, (2013).

[13] Pope, I. and Sutton, I.: "The correlation between froth flotation response and collector adsorption from aqueous solution, Part I: Titanium dioxide and ferric oxide conditioned in oleate solutions". Powder Technology, 7, pp. 271-279, (1973).

[14] Povnnennykh, S.: "The use of infrared spectra for the determination of minerals". American mineralogist, 63, pp. 956-959, (1978).

[15] Qun, X.; Vasudevan and Somasundaran, P.: "Adsorption of anionic-nonionic and cationic-nonionic surfactant mixtures on kaolinite". Jou. of colloid and interface Sci. 142, No. 2, pp. 528-534, (1991).

[16] Raslan, M. F.: "Mineralogical and mineralogical characteristics of samarskite- $Y$, columbite and zircon from stream sediments of the ras baroud area, central eastern desert, Egypt". The scientific papers of the institute of mining of the Wroclaw university of technology, Wroclaw, Poland, No.126, Mining and geology, XII: pp. 179-195, (2009).

[17] Raslan, M. F. and Fawzy, M. M.: "Mineralogy and physical upgrading of fergusonite-Y and Hf-zircon from Abu Dob pegmatites, south eastern desert, Egypt", in preparation, (2017).

[18] Satur, V.; Calabia, P.; Hoshino, M.; Morita, S.; Seo, Y.; Kon, Y.; Takagi, T.; Watanabe, Y.; Mutele, L. and Foya, S.: "Flotation of rare earth minerals from silicatehematite ore using tall oil fatty acid collector". Min. Eng., 89, pp. 52-62, (2016).

[19] Somasundaran, P. and Ananthapadmananthan, P.: "Advances in mineral processing". Littleton: Society of mining engineers of AIME, (1986).

[20] Wang, L.; Yuehua, H.; Jiapeng, L.; Yongsheng, S. and Wei, S.: "Flotation and adsorption of muscovite using mixed cationic-nonionic surfactants as collector". Powder Technology 276, pp. 26-33, (2015).

[21] Zhang, J. and Edwards, C.: "A review of rare earth mineral processing technology, In: $44^{\text {th }}$ annual meeting of the Canadian mineral processors". CIM, Ottawa, pp. 79102, (2012). 